\title{
Tras los concursos
}

\author{
Fernando Pérez Oyarzun Profesor, Facultad de Arquitectura, Diseño y Estudios \\ Urbanos, Pontificia Universidad Católica de Chile
}

Los concursos de arquitectura parecen entregar garantías de la calidad del resultado pueden promover a arquitectos jóvenes y evidencian las tensiones arquitectónicas presentes en un momento dado. El análisis a sus variantes permite entender mejor la problemática existente en torno a ellos.

\section{Behind the competitions}

\author{
Fernando Pérez Oyarzun Professor, School of Architecture, Design and Urban Studies, \\ Pontificia Universidad Católica de Chile
}

Architectural competitions seem to incorporate guarantees of quality results; they may promote the careers of young architects; they reveal the tensions within the architectural field at a given moment. Analyzing their variants can help to understand the problems surrounding the genre.
Abordar y comprender mejor la temática de los concursos de arquitectura exige tomar distancia respecto de una práctica tan habitual como problemática. Su persistencia histórica, ya de varios siglos, debería permitirnos reflexionar sobre su sentido profesional y disciplinar. Tal esfuerzo es el que, en una reflexión de corte casi filosófico, propone Alberto Montealegre en el texto Derecho, fines y medios: la declinación del concurso de arquitectura publicado en este número. Intenta poner de relieve el contrato social que, según él, sostiene la institución de los concursos. Su postura que es más bien escéptica, plantea que tales bases tienen un carácter problemático, el que se acentúa bajo las actuales condiciones económicas y de ejercicio profesional.

También es crítica la opinión de Jorge Heitmann en relación a las alternativas del concurso para una nueva Ciudad administrativa en Corea y al rol que en ella habría jugado el proyecto de DOGMA/OFFICE, no reconocido por el jurado en la segunda etapa del concurso. Sin embargo, más allá de la tantas veces cuestionada actitud del jurado, la propia convocatoria de un concurso de escala mundial testimonia la vigencia de la práctica del concurso a pesar del carácter frecuentemente problemático de sus resultados.

Los concursos de arquitectura, institución y práctica extraña para otras disciplinas del mundo de la construcción, se remontan, a lo menos, al primer renacimiento. Algunos historiadores encuentran rastros de esta práctica en períodos anteriores ${ }^{1}$, aunque no necesariamente asumían su forma actual. Entre los más célebres concursos registrados por la historia está aquel convocado en la ciudad de Florencia para la construcción de la cúpula de Santa María dei Fiori, en que el primer premio habría sido compartido Brunelleschi y Ghiberti². A diferencia de lo que ocurre con la pintura, donde los concursos aparecen como una práctica menos frecuente, la arquitectura y la escultura son artes en que el proyecto, como visión anticipada de la obra, tiene una importancia fundamental y donde la magnitud de los recursos implicados favorece el esfuerzo por asegurar con antelación la calidad del resultado.

Tal vez un ingeniero, más acostumbrado a competir en base a sus antecedentes curriculares podría preguntarse: ¿no son el prestigio o el talento reconocido de un arquitecto garantía suficiente de la calidad de sus resultados? $\mathrm{Al}$ parecer la respuesta que históricamente se ha dado a esta pregunta ha sido negativa ${ }^{3}$. Por el contrario y como se pone de relieve en el caso de DOGMA/ OFFICE en Corea, los concursos han dado ocasión a que arquitectos aún no consagrados, emerjan frente a arquitectos de prestigio y trayectoria. A este estado de cosas parecen confluir dos circunstancias propias de la arquitectura. La primera es la relativa dependencia que el resultado de una obra tiene de las circunstancias que la rodean. Ellas van desde el ambiente cultural hasta la sensibilidad y la actitud del cliente. De este modo aún arquitectos de gran talento han sido incapaces de mantener un nivel parejo en sus obras. La segunda razón tiene que ver con algo que ya Aristóteles señaló como propio de las disciplinas artísticas: ellas no producen soluciones necesarias sino posibles. Las artes, y en este aspecto la arquitectura participan de tal condición,
Improving our grasp of the issues involved in architectural competitions requires taking distance from this very familiar, but problematic practice. The historical persistence of the phenomenon, over several centuries now, provides us the perspective needed to reflect on its meaning for the discipline and the profession. This is what Alberto Montealegre does in a rather philosophical article in the present issue, entitled Derecho, fines y medios: la declinación del concurso de arquitectura, focusing on the social contract that he says underpins architectural competitions as an institution. From his rather skeptical point of view, this underpinning is problematic, and the problems are accentuated by current economic conditions and the state of the architectural discipline and profession.

Jorge Heitmann is also critical in considering the alternative submissions for a new administrative city in Korea, and the role that the DOGMA/OFFICE proposal played in the process. It was eliminated by the jury in the second round of the competition. Beyond the jury's widely questioned attitude, however, the very phenomenon of a worldwide call for submissions is evidence that the architectural competition is alive and well, even if results are sometimes problematic.

From the point of view of other disciplines in the world of building, competitions may appear a peculiar institution and a strange practice, though they go back at least to the early Renaissance in architecture. Indeed, some historians see traces of architectural competition in earlier periods ${ }^{1}$, if not in the form they take today. One of the most celebrated competitions in the historical record is the one held in Florence for construction of the cupola of Santa Maria dei Fiori, where the first prize was shared by Brunelleschi and Ghiberti ${ }^{2}$. Architecture, like sculpture, but unlike painting where competitions are less common, is an art in which the proposal, as an anticipatory vision of the work, has fundamental importance, and the magnitude of resources involved leads to very serious effort at this stage.

Engineers, more accustomed to competing on the basis of background and experience, might very well ask, Isn't the prestige or recognized talent of an architect guarantee enough of the quality of his results? History seems to have answered this question in the negative ${ }^{3}$. Indeed, as the DOGMA/ OFFICE in Korea case shows, competitions have provided opportunities for less recognized architects to emerge despite the presence of prestigious and experienced elders. Two peculiar factors to our discipline seem to be at play here. The first is the fact that architectural work is dependent on surrounding circumstances. One set of such circumstances is intangible, ranging from the general cultural climate to clients' attitudes. Given these factors, even highly talented architects find themselves unable to maintain an even level in their work. A second type of circumstance has to do with what was identified already by Aristotle as a factor inherent to artistic effort, the fact that it produces not necessary solutions, but possible solutions. Thus the arts, including architecture, are not constrained to a given number of good or feasible 
1 En su texto El arquitecto en la Edad Media, en oriente y occidente, una profesión, Spiro Kostof señala: "A veces se establecía una com entre los posibles candidatos paria trabajo, o se solicitaba una opinión

profesional de varios arquitectos para

prer cual parecía ser el más comp para.

asi en el caso de la Catedral de Can-

terbury para

franceses e ingleses sin que lograron

ponerse de acuerdo entre llog". p. 86.

2 Como en tantos concursos este es un resultado complejo qu un compromiso de parte del jurado. Por circunstancias históricas que no entemente su suprente claras, apa-

en el desarrollo de la obra.

${ }^{3}$ En su relato acerca del desarrollo de la construc dei Fiori, Ross King subraya el desencanto de Brunelleschi, obligado a competir por el diseño de la lintern haber demostrado por largos años su capacidad en la construcción de la cúpula.
1 In his piece on the architect in the middle ages in East and West, in The architect: chapters in the history of the profession, Spiro Kostof remarks "that competitions were sometimes mplemented among possible canopinions of different architects we solicited to see which candidate was most completely qualified for the job. Thus, a number of French and English architects were brought together to make a decision about the repair of the choir at Cabur Cathedral though they fired to reach a consensus". p. 86.
${ }^{2}$ As in so many competitions, this was a complex outcome that part of the jury. For historical -apparently Brunelleschi's technic supremacy was the determining factor- he played the leadr the design process.
${ }^{3}$ In his account of the construction of Santa Maria dei Fiori, Ross King stresses Brunelleschi's vexation at having to compete for the design of the lantern housing of the cupola, having already demonstrated his abilities during the long years of construction.

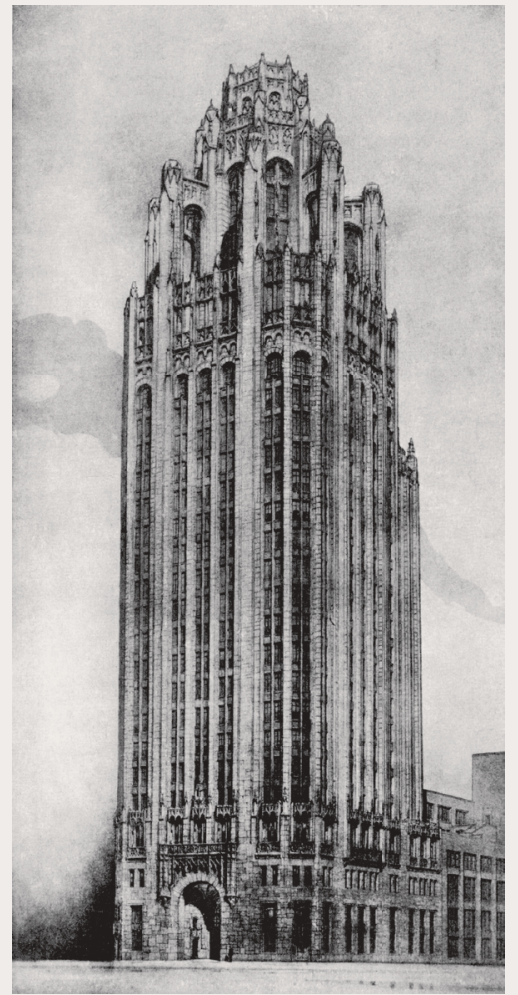

01

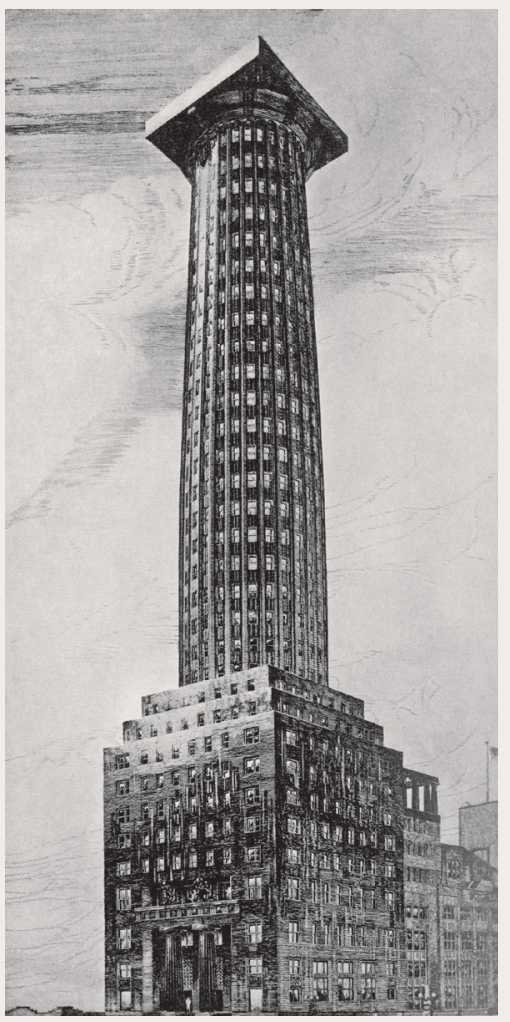

03

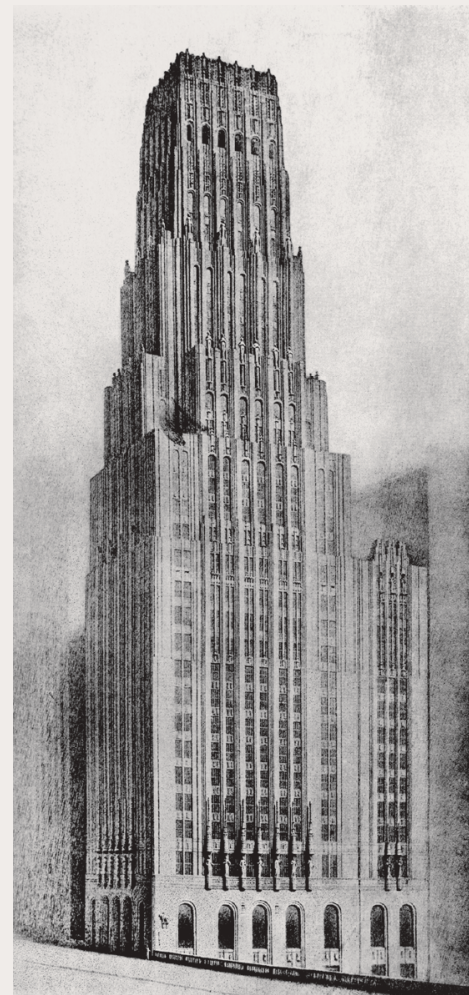

02

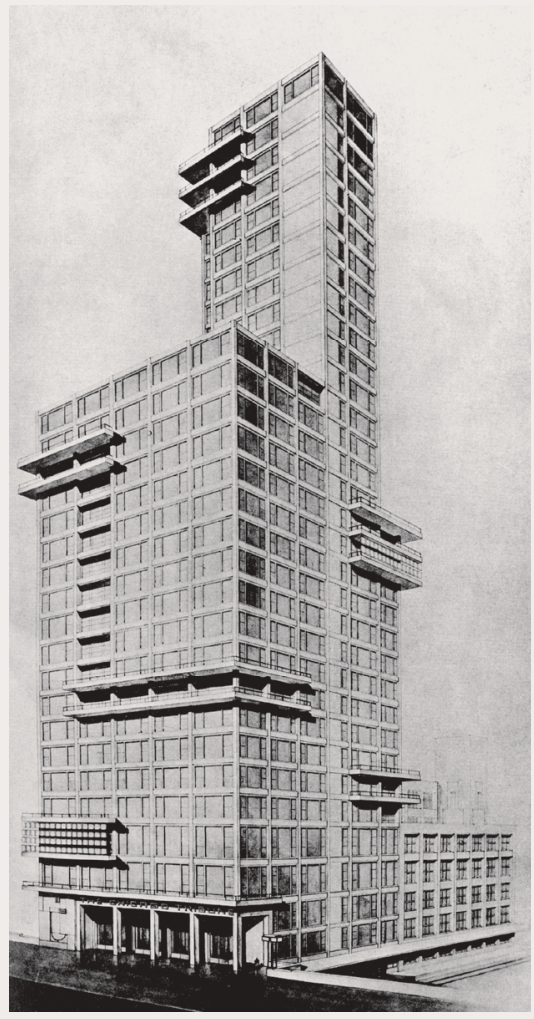

Concurso del Chicago Tribune, 1922

01 Anteproyecto ganador, John Mead Howells y Raymond M. Hood.

2 Segundo premio, Eliel Saarine

03 Anteproyecto de Adolf Loos.

04 Anteproyecto de Walter Gropius y Adolf Meyer.

05 Anteproyecto de Max Taut.

Chicago Tribune competition, 1922

01 Winning proposal, Jonn

02 Second prize, Eliel Saarinen.

03 Adolf Loos's proposal.

04 Walter Gropius and Adolf Meyer's proposal.

05 Max Taut's proposal.

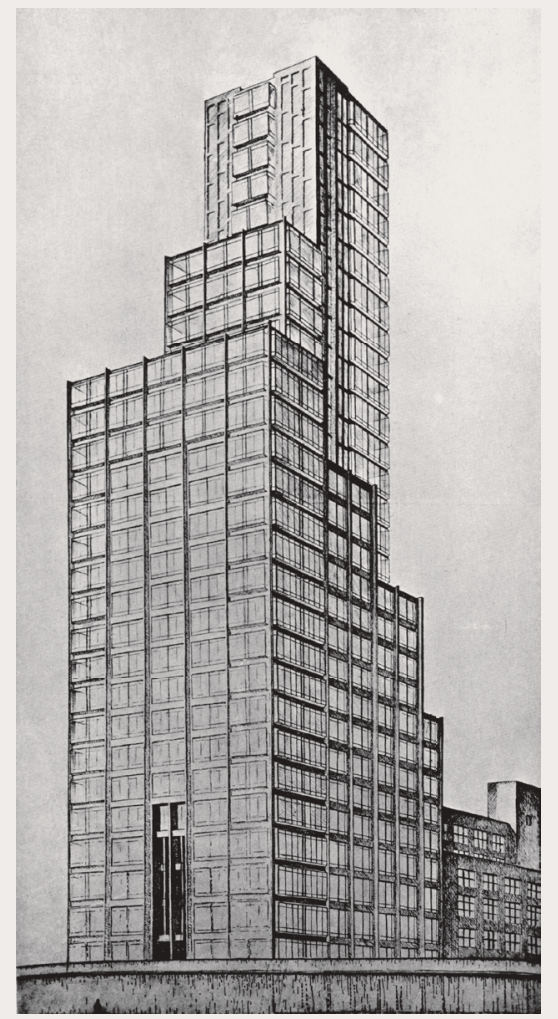

05 
4 "La ciencia nocturna, en cambio, vaga a ciegas. Duda, tropieza, retrocede suda, se despierta sobresaltada. Cuestionándolo todo se busca, se interroga se corrige sin parar. Es una especie de taller de lo posible donde se elabora lo que se convertirá en materia de ciencia". En La estatua interior, p. 299.

5 El proyecto de Loos, una column dórica de granito negro levantada sobre una base ha permanecido como un objeto polémico, desafia simultáneamente la sensibilidad neogótica que se impuso en el con- curso como la postura vanguardista de torres asbtractas. Panayotis Tournikiotis ha puesto de relieve esta idea no fue tan excepcional en el contexto del concurso. Los arqu presentaron variaciones sobre el mismo tema aunque menos radicales que la de Loos.

6 El concurso fue ganado por Boris lofan con un proyecto monumental corono coronado por una escular proyecto pa sido considerado como extemporaneo por gran parte de moderna srin de la arquitecturá de Moscú como la que presenta Kart Schlögel (Moscow) nos muestra que en muchos sentidos era esta una tradición viva en el Moscú de los años 30 como lo era también la . proyecto de Melnikov también fue ignorado en este concurso.

7 En efecto, Lucio Costa logró persuadir al entonces ministro Gustavo Capanema de anular el veredicto que habí premiado el proyecto de Archi mede Memoria y encargarlo a un joven equipo de arquitectos brasileros liderados por él mismo y que contaba con Ia asesoría de Le Corbusier.
4 "The science of the night, on the other hand, stumbles, retreats, sweats, awakens in fright. Questioning everything, it seeks, inquires, and corrects itself unceasingly. It is a sort of workshop of the possible in which that which will become the stuff of science is created". Translation from the p. 299

5 Loos's proposal, a Doric colum of black granite on a base has remained an object of controversy challenging the neo Gothic sensibi ity that came to dominate the competition, as well as the avant-gard posture with its abstract towers. Panayotis Tournikiotis has stress that the idea was not all that exceptional in the context of the competition. The architects Gerhar Freeman and Patelski submitted variations on the same theme though less radical than Loos's.

${ }^{6}$ The competition was won by Boris Iofan with a monumental project crowned by a sculpture. Much historical discussion of moden architecture has considered it anachronistic However, a view of
Moscow such as that presented by Kart Schlögel (Moscow) shows us that in many ways this was as much a living tradition there in the 1930 as were New York's skyscrapers in that city Melnikov's proposal was also ignored in the competition.

In fact, Lucio Costa managed annul the verdict that had chosen and commission a young team of and com headed, with Le Corbusier acting as an adviser
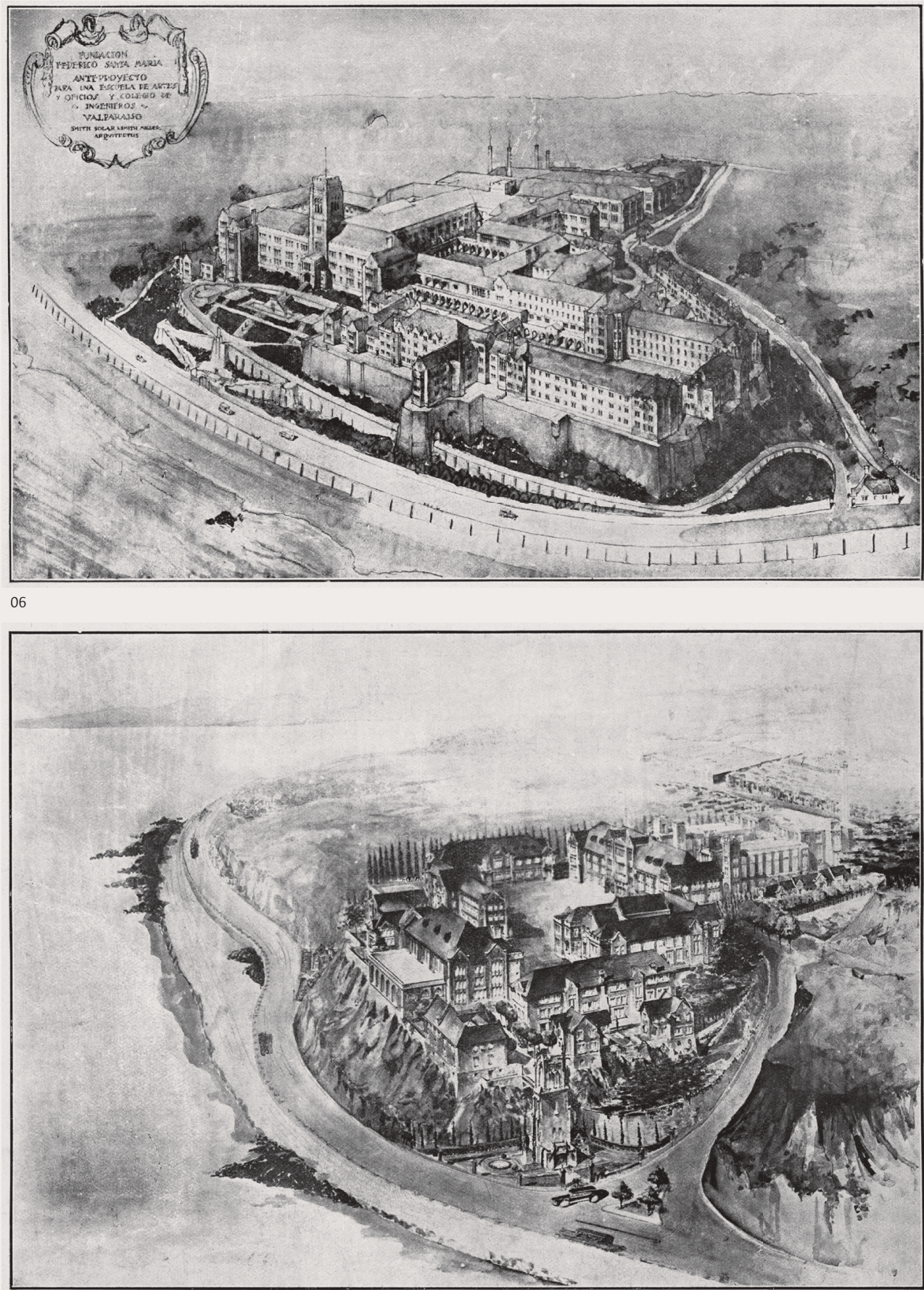

Concurso Universidad Federico Santa María, 1927.

06 Anteproyecto ganador de Smith Solar y Smith Miller.

07 Anteproyecto de Valdivieso y de la Cruz.

Universidad Federico Santa Maria competition, 1927.

06 Winning proposal by Smith Solar y Smith Miller.

07 Valdivieso and de la Cruz's proposal. 
no se limitan a escoger entre unas cuantas posibilidades, aún buenas o factibles, sino que se empeña en generar nuevas alternativas. Es difícil, por tanto, prever o visualizar una solución arquitectónica sin haberla hecho alcanzar un cierto grado de completitud y desarrollo. Eso es precisamente lo que un proyecto se propone y lo que un concurso pretende explotar. En un cierto sentido ellos pueden ser vistos, tomando las palabras de François Jacob acerca de la investigación científica, como un taller de lo posiblet.

Sean cuales sean las razones que han instalado la institución de los concursos en el centro de la práctica de la arquitectura, es un hecho que ellos han adquirido una importancia capital. En primer lugar, porque abriendo la posibilidad de encargo a arquitectos jóvenes, han actuado como revulsivos al esclerosamiento de la estructura profesional. En segundo lugar, porque nos permiten conocer con particular nitidez las tensiones arquitectónicas que operan en un momento dado. Por último, los concursos en su condición de públicos y abiertos, aparecen con un signo político de apertura y publicidad: una suerte de antídoto en contra de las complicaciones derivadas de los beneficios económicos asociados a los encargos, y una manera de difundir y legitimar iniciativas públicas o privadas relevantes.

Hay que recordar que el rol de los concursos no se ha consumado siempre en la construcción del proyecto ganador. No son pocas las ocasiones en que un proyecto no vencedor permaneció como referencia clave en el imaginario colectivo de los arquitectos. Es contra este telón de fondo que deberían verse algunos de los resultados polémicos de concursos que recoge este número de $\mathrm{ARQ}$.

En el s. XIX la institución de concursos públicos parece haber estado bien establecida. Aquel que se convocó para el edificio de la Ópera de París reuniendo a más de 170 participantes es uno de los más ilustres y anticipa una actitud del poder público francés que se reiterará años más tarde con concursos como aquellos para el Centro Pompidou, la Ópera de la Bastilla o la Tête Défense.

En cuanto a su significación historiográfica, el s. XX está jalonado de concursos relevantes en los que es posible percibir una cierto estado de cosas de la arquitectura del momento. En 1922, por ejemplo, el concurso para el Chicago Tribune reunió a más de 260 arquitectos reflexionando creativa y críticamente sobre la temática del rascacielos de oficinas. El concurso fue ganado por John Mead Howells y Raymond M. Hood. Sin embargo, el proyecto de Eliel Saarinen, que obtuvo el segundo lugar, ha sido considerado más influyente en el diseño de rascacielos. El concurso reunió, entre muchos, a figuras como Gropius y Meyer, los hermanos Taut, y Adolf Loos, poniendo de relieve las diversas posturas que se perfilaban a comienzos de la década del 20 sobre el nuevo programa del rascacielos de oficinas ${ }^{5}$.

Los proyectos para el concurso del Palacio de las Naciones en Ginebra llamado en 1926 y el del Palacio de los Soviets en 1929, representan grandes fracasos de Le Corbusier. En el primero ni siquiera fue seleccionado en el grupo de cinco arquitectos llamados a colaborar en el proyecto final. Sin embargo, el actual edificio de Julien Flegenheimer y Henri-Paul Nénot es seguramente menos conocido por los arquitectos que el de Le Corbusier, ampliamente publicado y analizado. Otro tanto ha ocurrido en el segundo, en relación al de Boris Iofan, que aunque ganó no llegó a ser construido ${ }^{6}$.

El concurso para el Faro de Colón, reseñado en este número por Robert González como un esfuerzo dentro del movimiento panamericanista, se inscribe en esa misma saga de concursos internacionales. La idea había surgido a mediados del s. XIX pero sólo se concretó en 1931 convocando a más de 400 arquitectos de todo el mundo. El resultado que dio por ganador a Joseph Lea Gleave con la aparente influencia de Frank Lloyd Wright que formaba parte del jurado, representa el caso típico de la promoción de un arquitecto joven y desconocido.

En Latinoamérica el concurso para el Ministerio de Educación y Salud en Río de Janeiro de 1936 fracasó como instancia para seleccionar el proyecto, pero produjo uno de los edificios más interesantes del período7. Tres décadas possibilities, but eager to create new alternatives. As a result, it is difficult to visualize or foresee the effectiveness of an architectural solution unless it has reached a certain degree of completeness and development. This is precisely what competitions aim to encourage and take advantage of, and what architectural proposals are designed to achieve. In a sense, these competitions may be seen, to borrow François Jacob's words on scientific research, as a workshop of the possible 4 .

Regardless of the reasons for which competitions have assumed the place that they have in architecture, that place is indubitably central and have the greatest consequence. First, by providing opportunities for commissions to young architects, competitions combat the profession's sclerotic tendencies. Second, competitions reveal with special clarity the tensions in the discipline at a given moment. And finally, as a public process, they are a political sign of openness, a sort of antidote to the complications associated with the economic benefits that accompany commissions, and a way of publicizing and legitimizing major public or private initiatives.

We must remember that competitions have not always culminated in the construction of the winning design. On more than a few occasions, winning projects have simply taken up a lasting place as key referents in the collective architectural imagination. It is against this backdrop that we must see some of the controversial competition outcomes discussed in this issue of ARQ.

In the nineteenth century, public competitions seem to have been a well-established institution. The competition for the construction of the Paris Opera is one of the most celebrated. It attracted over 170 participants and prefigured an attitude of the French government that was to make itself evident years later with competitions for buildings such as the Pompidou Center, the Bastille Opera and the Tête Défense. In terms of its architecture-historical significance, the twentieth century is marked by a series of important competitions that are snapshots of the state of architecture at their respective times. In 1922, the Chicago Tribune competition drew the creative and critical reflections of over 260 architects on the theme of skyscraper office buildings. Though the competition was won by John Mead Howells and Raymond M. Hood, Eliel Saarinen's proposal, which took only second place, has been considered the most influential in terms of its effect on subsequent skyscraper design. Among many others, figures such as Gropius and Meyer, the Taut brothers, and Adolf Loos participated, profiling the variety of postures prominent in the early 1920s regarding office skyscrapers 5 .

Le Corbusier's proposals for the 1926 Palace of Nations competition in Geneva and the 1929 Palace of the Soviets competition were great failures. In Geneva, he was not even among the five architects asked to work on the final proposal. However, the building that was eventually built, designed by Julien Flegenheimer and Henri-Paul Nénot, is surely less known by architects than is Le Corbusier's design, which has been widely published and analyzed. In the second case, Boris Iofan won, but the project was not finally built ${ }^{6}$.

The competition for the Columbus Lighthouse competition, examined by Robert González in this issue as a part of the Pan-American movement, is also a part of the saga of international competitions. The idea for this competition had emerged in the mid-nineteenth century, but it was held only in 1931. Over 400 architects from around the world participated. The triumph of Joseph Lea Gleave under the apparent influence of Frank Lloyd Wright on the jury is a representative case of the an unknown young architect's career being promoted by a competition.

In Latin America, the 1936 competition for the Ministry of Education and Health in Rio de Janeiro failed as a process for selecting the building's design, but produced one of the most interesting buildings of the period? ${ }^{7}$. Three decades later, the PREVI competition in Lima, during the presidency of architect Fernando Belaúnde Terry, put the ideas of modern architecture at the service of social housing needs. The competition's invitations to figures such 
más tarde, el concurso de PREVI Lima, promovido durante la presidencia del arquitecto Fernando Belaúnde Terry constituyó una iniciativa destinada a poner las ideas de la arquitectura moderna al servicio de las urgencias de la vivienda social. La presencia de invitados como James Stirling, Christopher Alexander o Aldo van Eyck, así como la constitución de un jurado internacional, entre ellos el arquitecto José Antonio Coderch, dan cuenta de la ambición del concurso.

En Chile también una larga lista de concursos han jugado un rol significativo en el desarrollo de la arquitectura del s. XX. Proyectos como aquellos para el Club de la Unión, el restaurant Cap Ducal ${ }^{8}$ y la Universidad Federico Santa María se resolvieron mediante concursos privados?.

La polémica acerca de los resultados y los procedimientos no ha estado ausente en algunos de tales concursos. Así aquel para la Escuela de Medicina de la Universidad de Chile ganado por Juan Martínez, provocó una gran decepción a oficinas como las de Valdés, Castillo y Huidobro. Otro tanto ocurrió con el proyecto que con enorme esfuerzo desarrolló la Escuela de Arquitectura de la UCV para el concurso de la Escuela Naval en Valparaíso. El concurso para el edificio de las Naciones Unidas en Santiago, ganado por Emilio Duhart, parece haber generado, en cambio, un gran consenso.

La institución de los concursos ha ido adquiriendo forma a lo largo del tiempo hasta llegar a lo que conocemos hoy día. Ciertamente existen variantes: concursos abiertos, por invitación o que combinan ambas posibilidades; en una o más etapas. Más allá de tales variantes, el hecho que importa destacar es que la institución del concurso se sostiene por la existencia de esa forma y que cualquiera de sus aspectos que se debilite pone en grave peligro su efectividad y aún su sentido.

El primero de tales aspectos son las bases. En su artículo El programa arquitectónico en las bases de un concurso Claudio Vásquez, quien tiene la experiencia de haber redactado las bases para el concurso del Liceo Alemán del Verbo Divino en Colina, también publicado en este número, pone de relieve la significación y la importancia de este aspecto del concurso. De paso, señala algunos casos célebres, incluyendo el reciente proyecto de OMA para el Centro de Congresos de Córdoba, donde la aplicación o no aplicación estricta de las bases ha tenido consecuencias decisivas en el resultado del concurso. Las bases, se refieren a dos aspectos normalmente: a la forma que ha de adquirir el proceso (bases administrativas) y a las condiciones que deben cumplir las soluciones (bases técnicas). La referencia de Claudio Vásquez a las ideas de Isidro Suárez permite recuperar ese notable esfuerzo por pensar la dimensión programática de la arquitectura, aquella que tiene que ver con las reglas y el sentido de sus formas. Las bases, que constituyen algo así como una prefiguración genérica del proyecto, deben lidiar con esa resistencia que tantas veces muestra la arquitectura para ser expresada a través de palabras. Sin embargo, la persistencia histórica de elementos como las memorias de proyecto y las especificaciones técnicas, nos dejan en claro la imposibilidad de evitar esa dimensión que juega en los concursos un rol de importancia, al proporcionar el marco en el que se da la discusión del jurado. La fidelidad a esa difícil previsión que son las bases hace muchas veces dificil el funcionamiento de los jurados. En un artículo publicado en el número 42 de la revista CA dedicado a los concursos, Jaime Márquez pone de relieve tales dificultades en relación a la reglamentación de los concursos, defendiendo la necesidad de una doctrina de los concursos ${ }^{10}$.

En ese mismo número, se publican tanto los resultados como la polémica a que dio lugar un concurso público para la sede del edificio de la empresa Shell ${ }^{11}$, atribuyendo a la composición y decisión del jurado la responsabilidad del desencanto que ha provocado el resultado. El jurado constituye ciertamente una pieza fundamental de la institución del concurso. La existencia de jurados, como en la administración de justicia, nos enfrenta a la dificultad de resolver en una instancia que busca con esfuerzo la objetividad a través as James Stirling, Christopher Alexander and Aldo van Eyck, along with the international jury, of which José Antonio Coderch was a member, reflect the competition's ambitiousness.

In Chile, too, a long list of competitions played a significant role in the unfolding of architecture in the twentieth century, with designs for the Club de la Unión, the restaurant Cap Ducal ${ }^{8}$, and Universidad Federico Santa María chosen in privately held competitions?

Controversy about the both process and results have not been lacking in these competitions. Thus, the awarding of the contract for the School of Medicine at the Universidad de Chile to Juan Martínez created great disillusionment in firms such as those of Valdés, Castillo and Huidobro. Similar reactions were evinced in relation to the proposal developed with such effort by the School of Architecture of Universidad Católica de Valparaíso for the Naval School in Valparaíso. The competition for the United Nations building in Santiago, which was won by Emilio Duhart, seems, on the other hand, to have evoked a major consensus.

Architectural competitions as an institution took shape over a long period before becoming what they are today. Though there are variations on the theme, including open and invitational competitions, as well as a hybrid of the two, and competitions involving one phase of judging or more, the basic structure of the competition is a given at this point in history, and if any of the facets of the form are out of place the effectiveness and even meaning of the competition are jeopardized.

The first facet of the competition process that presents itself for examination is the rules, and one article in this issue explores this point of view. In the article El programa arquitectónico en las bases de un concurso, Claudio Vásquez, who has himself redacted competition rules for the Liceo Alemán del Verbo Divino competition in Colina highlights the significance of this element of the competitive process. In passing, he touches on some well-known cases, including the recent OMA design for the Centro de Congresos in Córdoba, where application of the rules or laxity had decisive impact on the result of the competition. Rules normally address two areas: the procedural issues (administrative rules) and the conditions that submissions must meet (technical rules). Claudio Vásquez's reference to the ideas of Isidro Suárez fruitfully reminds us that notable effort to think through the programmatic dimension of architecture, which deals with the meaning and mold of its forms. Competition rules, as a sort of generic prefiguration of the design, must somehow overcome the resistance that architecture opposes to verbal formulation. However, the historical persistence of architects' project notes and writings, as well as verbally formulated technical specifications, clearly show that it is impossible to sidestep this dimension, and in competitions it provides the framework for a jury's discussion. Commitment to the rules as an embodiment of the demanding process of prefigurement sometimes makes juries' work difficult. In an article published in issue number 42 of CA, which focuses on competitions, Jaime Márquez stresses the need for a competition doctrine, adducing as a basic reason such difficulties as the above in the process of overseeing competitions ${ }^{10}$.

That same issue examines both the results of and the controversy on the public competition for the Shell headquarters ${ }^{11}$, attributing responsibility for the disenchantment provoked by the result to the jury's composition and consequent decision. However, juries are a fundamental piece of the competition as a present-day institution. As in legal systems, they are a societal response to the challenge of creating a process that must seek objectivity through a confluence of subjective perspectives. Clearly, architectural decisions take place in an intermediate space that is neither scientific objectivity nor subjective arbitrariness. The creation of a good jury is almost a form of art, for juries must be responsible to the interests and intentions of commissioning entities, while simultaneously reflecting the values of the profession 
8 Es conocido el hecho de que Roberto Dávila presentó una serie de alternativas en

- En el caso de la Universidad Federico Santa María se publicó un volumen con el contenido de los cuatro anteproyectos presentados. La excusa era que dada la calidad de los cuatro proyectos y a pesar haberse declarado ganador el de Smith Solar y Smith Miller convení conocer y aprovechar los aportes de es perceptible que, más allá de ello, se desea preservar un esfuerzo profesional e institucional que parece tener un valor más allá del hecho de elegir al arquitecto encargado de la obra. Los cuatro equipos invitados fueron: Valdivieso y de Cruz, Browne y Valenzuela, Smith Solar y Smith Miller, y Cruz Mont y Dávila. En el jurado estuvieron y Federico Montenegro. Actuó como sesor Álvaro Orrego. Ver Concurso Artes y Oficios y Colegio de Ingenieros osé Miguel Carrera.

10 Márquez, Jaime. "Hacia una doctrina de los concursos". En $C A$ № 43, p. 24.

Eliash, Humberto. "Una polémica vigente". En CA № 43 , pp. 70-72.
${ }^{8}$ As is known, Roberto Dávila preA number of alternatives in different styles for this competitio

${ }^{9}$ In the Universidad Federico Santa María case, a volume was publishe with the content of the four proposIs submitted. The reason given was that though the Smith Solar nd Smith Miller proposal had bee clared the winner, all four propos$s$ were of a quality that made them worthy of dissemination use. Beyond this, though, we can see that there was a desire to preserve this piece of the institution's history and the notable professional effor ssociated with it, which seemed to have value beyond their role project. The four teams invited we Valdivieso and de la Cruz, Browne and Valenzuela, Smith Solar and , Snd Cruz Montt and Dávite Alessandri, Enrique Costabata
Federico Montenegro. Álvaro Orrego acted in an advisory capacity See Concurso de anteproyectos para la de Artes y Oficios y Colegio de Ingenieros José Miguel Carrera.

10 Márquez, Jaime. "Hacia una dectrina de los concursos". In CA № 43 , p. 24 .

"Eliash, Humberto. "Una polémica vigente". In CA No 43 , pp. 70-72.

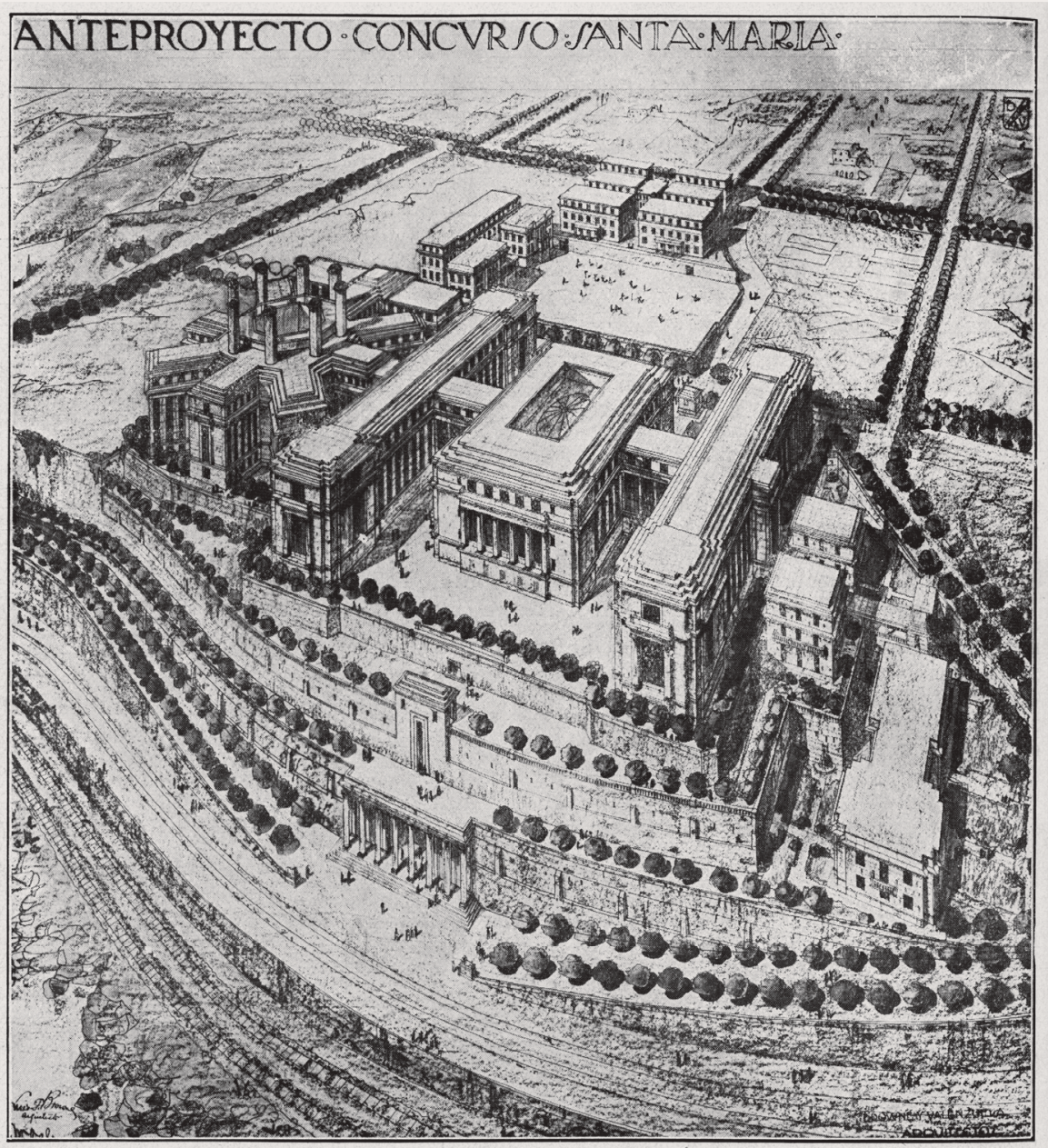

Concurso Universidad Federico Santa María, 1927. teproyecto de Browne y Valenzuela.

09 Anteproyecto de Alberto Cruz Montt y Dávila.

Universidad Federico Santa María competition, 192 08 Browne and Valenzuela's proposa 09 Alberto Cruz Montt and Dávila proposal.

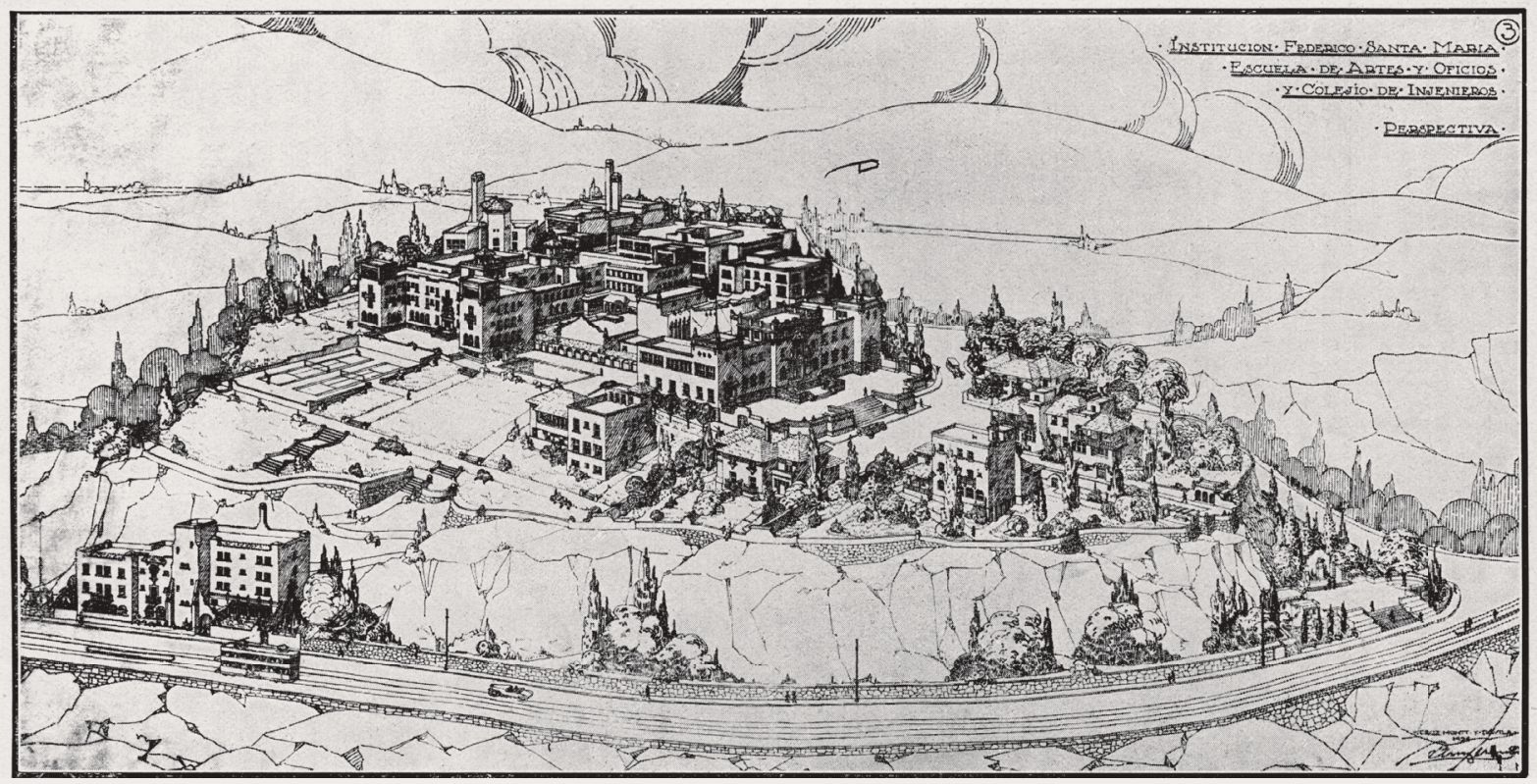


${ }^{12}$ Así ocurió, por ejemplo, en un concurso tan conocido como el llamado para tan conocido como el llamado para la nueva estación de Atocha en Madid, con su autor, Rafael Moneo, actuó sôlo en el rol de asesord

${ }^{13}$ En un artículo que será publicado Escefandra en Madrid Nichos señala el modo en que ha cambiado el rol del arquitecto en Inglaterra a este , to, limitando sus facultades. Otro tanto ocurre con algunas regulaciones suecas que limitan también el roly

14 En el primer caso el resultado es un edificio que se encuentra entre los mas edficio que se encuentra entre los más solar chilena. Fue proyectado por Sergio Larrain, Emilio Duhart, Mario
Pérez de Arce y Alberto Piwonka, con la participación de Oscar Praguer como paisajista. El desarrollo completo del colegio tomó varias décadas. En los últimos años estuvo a cargo de los ultimos años estuvo a cargo de Asociados.
${ }^{12}$ For example, in as well-known a competition as the one held for the new Atocha Statione held for the new Atocha Station in Madrid Where the proposal's architect, adviser during acted only as an ${ }^{13}$ In a forthcoming article in Escafandra in Madrid, Nicholas Escafandra in Madrid, Nicholas ray com this regard, which has been limited. Swedish regulations also limit the architect's role and presence in the presence in the construction phase.

14 In the former case, the result was one of the most notable was on the most It was designed by Sergio It was designed by Sergio Larrain, and Albert, Pino
Praguer participating as landscape architect. The complete realization of the project lasted several decades, and in the last years it was the responsibility of Mario Pérez de Arce y Asociados. de la confluencia de subjetividades y hace evidente cuánto las decisiones de arquitectura se sitúan en un terreno que no es el mismo de la objetividad científica pero tampoco corresponde al de una arbitrariedad subjetiva. La constitución de un buen jurado es casi una forma de arte: debe representar con claridad los intereses y las intenciones del mandante, pero a la vez ser capaz de representar los valores de la disciplina arquitectónica, a través de arquitectos con juicio crítico certero. La experiencia demuestra que no siempre un jurado compuesto de figuras arquitectónicas relevantes es el que mejor funciona. El trabajo dedicado de los miembros del jurado y el diálogo que idealmente debería darse entre ellos son fundamentales. En la conducción de este, el rol de su presidente puede resultar decisivo. Tal diálogo es significativo no sólo porque suele ser la condición de un adecuado resultado del concurso sino también porque, a su manera, representa el diálogo que se da entre la sociedad y los arquitectos.

La decisión del jurado no pone necesariamente fin a los avatares arquitectónicos que se detonan con un llamado a concurso. Si bien lo normal y hasta cierto punto lo habitual es que el proyecto premiado en un concurso llegue a construirse, ello no siempre ocurre.

Muchas veces las bases dejan el espacio para que el mandante tome esa decisión con autonomía respecto a la decisión del jurado. Uno de los proyectos que en este número se publica, el Santiago College, se inscribe en esta condición. Hace varias décadas, aunque en circunstancias diversas, ocurrió algo similar con el colegio Saint George. Es lamentable que las virtudes de un proyecto que exploraba de manera interesante nuevas posibilidades de la tipología de edificios escolares modernos no haya podido concitar el necesario consenso.

El proceso que sigue al concurso suele proponer problemas adicionales. El proyecto de Smiljan Radic, Eduardo Castillo y Ricardo Serpell pone en evidencia esas dificultades. Es destacable que la decisión sobre un centro administrativo tan importante para la ciudad de Concepción haya sido tomada en un concurso abierto y que el jurado haya seleccionado un proyecto tan radical como cualificado. Por la otra, es lamentable que al menos durante parte del desarrollo de la obra sus autores no hayan llevado a cabo la supervisión de obra. Por diversas razones esa situación se ha dado en otros concursos a nivel internacional ${ }^{12}$. Al margen de imprevisiones o equivocaciones, la tensión de fondo que aquí se pone en evidencia es la posibilidad del arquitecto de ejercer su acción durante el proceso de ejecución de la obra. Especificidades programáticas y sobre todo aumentos presupuestarios surgidos durante la construcción son las razones más frecuentemente esgrimidas para defender esta decisión ${ }^{13}$. Resolver de manera adecuada tales tensiones está entre los desafíos más importantes que los arquitectos deberán enfrentar en el futuro. Ello no tanto por defender posiciones personales o gremiales sino para garantizar que la arquitectura pueda ofrecer a la sociedad lo mejor de sí y el arquitecto no quede relegado a un papel de proveedor de imágenes.

A pesar de todas las dificultades que la institución de los concursos hace presente, ella ha manifestado particular salud en determinados ámbitos. De los concursos que se publican en este número llama la atención el número de casos que se refieren al ámbito educativo. De hecho, la mayor parte de ellos corresponde a edificios escolares o universitarios. En el caso del concurso para el Liceo Alemán del Verbo Divino, ganado por el equipo de Felipe Assadi, Mathias Klotz, Francisca Pulido, Pablo Riquelme, Trinidad Schönthaler y Renzo Alvano, y a juzgar por el estado de avance de la construcción, parece haber funcionado fluidamente desde la redacción de las bases hasta su realización constructiva. Tras él emerge la tradición de una congregación religiosa dedicada a la educación que parece haber confiado en el mecanismo de los concursos como modo de lograr sus edificios. Este se suma a dos concursos tan significativos como el del colegio del Verbo Divino en Las Condes a finales de la década del cuarenta y el del Liceo Alemán as represented by architects with fine critical judgment. Experience shows that prestigious architects do not necessarily make for the best-functioning jury. Dialogue and devotion to the task are equally fundamental, and the role of the person chairing the jury can be decisive. Serious dialogue is significant not only as a guarantor of good outcomes, but also because it serves as a microcosm of the ongoing dialogue between a society and its architects.

Juries' decisions do not necessarily put an end to the architectural avatars that are spawned by a competitive call for proposals, for winning designs are normally -one might say habitually, but one cannot say invariably- built in the end.

Often, competition rules leave latitude for commissioning entities to make their final decisions independent of juries' opinions. The Santiago College proposal published in this issue is one example, and the Saint George case some decades ago, though the circumstances were different, is another. It was unfortunate that a proposal that so interestingly explored new possibilities for modern school typologies did not evoke the necessary consensus.

The process subsequent to the competition can also create problems, as the case of the Smiljan Radic, Eduardo Castillo and Ricardo Serpell project demonstrates. It is remarkable that the decision on this administrative center so important for the city of Concepción was made in an open competition, and that the jury should have selected so radical a proposal. Lamentably, however, the architects failed to thoroughly supervise the construction work. For various reasons, such situations have occurred in other international contexts as well ${ }^{12}$. Looking beyond the issues of unforeseen factors and mistakes, this points to an underlying tension that is inherent in the architect's ability to take action during the execution of a work. Programmatic specifications and budget increases during construction are the most frequent reason adduced for such action ${ }^{13}$. Resolving this tension effectively is one of the most important challenges that architects will face in the coming years not in terms of tensions involving their personal interests or positions, or those of the architectural trade, but in terms of ensuring that architecture can give society the best of itself, and that the architect is not relegated to the position of an image provider.

Despite all the difficulties that the institution of competitions faces, it has shown itself to be quite healthy in certain areas. The competitions examined in this issue include a notable number of educational projects (school and university buildings). The Liceo Alemán del Verbo Divino competition, which was won by a team comprising Felipe Assadi, Mathias Klotz, Francisca Pulido, Pablo Riquelme, Trinidad Schönthaler and Renzo Alvano, which is currently in construction, seems to have functioned flowingly from the writing of the rules to the building phase. Behind this success we see the weight of the tradition of a religious order dedicated to education, one that has evidently trusted competition as a mechanism since the 1940s, when it built the Verbo Divino in Las Condes, and the Liceo Alemán twenty years later ${ }^{14}$. The competition for the new Scuola Italiana, which was won by Teodoro Fernández, Sebastián Hernández and Milva Pesce, is also in this tradition, as is, in a sense, the Santiago College competition, whose second-place proposal by Juan Enrique Barros, Alberto Moletto, Juan Francisco Ossa, Álvaro Ramírez, Horacio Schmidt Cortés, Horacio Schmidt Radic, and Martín Schmidt, we publish here.

The tradition of competitions for educational buildings reflects confidence in the competitive process on the part of commissioning educational entities, a confidence that has not only generated a series of interesting school buildings, but that has promoted continuing reflection about educational buildings in general. Developments of the patio, for example, appear in both the Liceo Alemán and Santiago College proposals. 
veinte años más tarde ${ }^{14}$. El concurso para la nueva Scuola Italiana, ganado por Teodoro Fernández, Sebastián Hernández y Milva Pesce, se inscribe en esta misma tradición. En cierto modo lo hace también el concurso para el Santiago College del cual se publica el segundo premio concedido a Juan Enrique Barros, Alberto Moletto, Juan Francisco Ossa, Álvaro Ramírez, Horacio Schmidt Cortés, Horacio Schmidt Radic y Martín Schmidt.

Esta tradición de concursos en el ámbito educacional, hace presente una confianza de los mandantes en las posibilidades de los concursos. Esta ha permitido no solamente generar una serie de edificios de interés sino también dar continuidad a una reflexión sobre el tema del edificio educativo. Las elaboraciones sobre el patio, por ejemplo, aparecen tanto en los proyectos del concurso del Liceo Alemán como en el del Santiago College.

Otro tanto ocurre con la cuestión del paisaje tanto urbano como geográfico. Este aparece obviamente en el concurso para el parque Juan Pablo II, continuación de un proyecto también iniciado vía concurso, y asimismo en el de la Scuola Italiana, en cuyo fundamento juega un rol protagónico. Todo ello nos recuerda el rol que la oportunidad del concurso representa para el desarrollo de ideas arquitectónicas. Prueba de ello es el proyecto para un Orquideorama de Felipe Mesa, Alejandro Bernal, Camilo Restrepoy Paul Restrepo. En este, tanto la circunstancia del concurso como su localización en el Jardín Botánico de Medellín, proporcionan la ocasión para ensayar una solución flexible y de inspiración orgánica, que a más de dialogar con el entorno, sea capaz de adaptarse a una amplia variedad requerimientos programáticos.

Referencia aparte merecen los dos concursos publicados de edificios de la Universidad Católica. No sólo nos recuerdan una fructífera tradición de concursos desde aquel para el campus San Joaquín hasta el de los terrenos de Alameda, Lira y Quito, ganado por Juan Ignacio Baixas y Enrique del Río. La terminación del Centro de Información Sergio Larrain García-Moreno, bajo la responsabilidad de Cecilia Puga y Patricio Mardones, a partir del proyecto de concurso ganado por Teodoro Fernández, Smiljan Radicy Cecilia Puga en 1994, muestra el largo curso, y los esfuerzos de desarrollo y adaptación que debe realizar una idea arquitectónica para llegar a concretarse, siendo a la vez fiel a las intuiciones originales y debiendo acoger circunstancias materiales y programáticas cambiantes.

Si es cierto que es el equilibrio entre todos los factores que confluyen a un concurso el que parece garantizar su éxito, no cabe duda que la calidad de la convocatoria constituye un elemento clave. Sin un conjunto de proyectos de calidad no es posible conseguir un buen resultado en un concurso y es esa mezcla de interés y entusiasmo la que parece mover a los arquitectos a participar en ellos. Hacer perdurar y a la vez perfeccionar esta práctica sólo puede hacerse sobre la base de una comprensión de la naturaleza misma del concurso y de su relación con la práctica de la profesión. En ello se juega no sólo una de sus dimensiones más significativas sino también una de sus conexiones más poderosas con la práctica social: esa problemática confluencia a la que aludía Montealegre, depende no sólo de la contextura interna de los concursos sino de lo que seamos capaces de hacer con ellos. ARQ

\section{Bibliografía}

Chicago Tribune Tower Competition. Academy Editions, Londres, 1980. / Fundación Federico Santa María. Concurso de anteproyectos para la Escuela de Artes y Oficios y Colegio de Ingenieros José Miguel Carrera. Sociedad Imp. y Lit. Universo, Valparaíso, 1927. / Jacob, François. La estatua interior. Tusquets editores, Barcelona, 1989. / King, Ross. Brunelleschi's Dome. Penguin Group, Londres, 2001. | Kostof, Spiro. El arquitecto: historia de una profesión. Cátedra, Madrid, 1984. | Schlögel, Karl. Moscow. Reaktion Books, Londres, 2005. / Tournikiotis, Panayotis. Adolf Loos. Princeton Architectural Press, Nueva York, 1994. / VVAA. CA N43. Colegio de Arquitectos de Chile A. G., Santiago, marzo de 1986.
The issue of urban and geographical landscape is another case. It comes to the fore in the parque Juan Pablo II competition, which is the continuation of a project also begun via competition, and in the Scuola Italiana, where it plays a fundamental role. All of this is a reminder that competitions provide opportunities for the development of architectural ideas. One more demonstration of the fact is the Orquideorama designed by Felipe Mesa, Alejandro Bernal, Camilo Restrepo and J. Paul Restrepo. In this case, both the circumstances of the competition and the site in the Botanical Garden of Medellín provided the opportunity to seek a flexible, organically inspired solution that is in dialogue with the surroundings while lending itself to a range of programmatic requirements.

The two competitions for buildings at the Pontificia Universidad Católica de Chile merit special mention. Not only do they remind us of a fruitful tradition of competitions stretching from the San Joaquín Campus project to the sites on Alameda, Lira and Quito streets awarded to Juan Ignacio Baixas and Enrique del Río. The Centro de Información Sergio Larrain García-Moreno construction of which was finally concluded under the responsibility of Cecilia Puga and Patricio Mardones based on a design by Teodoro Fernández, Smiljan Radic and Cecilia Puga chosen in a 1994 competition, demonstrates the lengthy development and adaptation that an architectural idea must go through on its way to realization, if it is to meet changing material conditions and programmatic parameters without losing sight of its original intuitive vision.

While balance among all the factors that go into a competition is the overarching factor that seems to ensure success, the initial call for proposals is obviously a key element. Without attracting a set of highquality proposals, a competition cannot reach a satisfactory outcome, and it is only by provoking the necessary mixture of interest and enthusiasm among architects that it can enlist their efforts. Perpetuating and improving the competition process requires understanding the nature of competitions and their relationship to professional practice. This is not only one of their most significant architectural dimensions, but also one of their most powerful connections with social practices, for that problematic confluence to which Montealegre refers depends not only on competitions' internal characteristics, but on what we are capable of doing with them. ARQ

\section{Bibliography}

Chicago Tribune Tower Competition. Academy Editions, London, 1980. I Fundación Federico Santa María. Concurso de anteproyectos para la Escuela de Artes y Oficios y Colegio de Ingenieros José Miguel Carrera. Sociedad Imp. y Lit. Universo, Valparaíso, 1927. / Jacob, François. La estatua interior. Tusquets editores, Barcelona, 1989. / King, Ross. Brunelleschi's Dome. Penguin Group, London, 2001. / Kostof, Spiro. El arquitecto: historia de una profesión. Cátedra, Madrid, 1984. / Schlögel, Karl. Moscow. Reaktion Books, London, 2005. / Tournikiotis, Panayotis. Adolf Loos. Princeton Architectural Press, New York, 1994. / VV.AA. CA N ${ }^{\circ}$ 3. Colegio de Arquitectos de Chile A. G., Santiago, March, 1986. 